\title{
Cytological Investigations on Some North Indian Bicarpellatae
}

\author{
Santosh Bala* and Raghbir C. Gupta \\ Department of Botany, Punjabi University, Patiala-147002, Punjab, India
}

Received December 8, 2010; accepted April 3, 2011

\begin{abstract}
Summary The present investigations have been made on 37 wild species including 76 accessions in 29 genera covering 3 families-Acanthaceae, Lamiaceae and Scrophulariaceae of the Bicarpellatae series of subclass gamopetalae. Chromosome numbers and detailed meiotic course, along with pollen fertility, have been studied for each species on its accession basis. New reports are recorded as B-chromosomes: Ajuga bracteosa $(n=32+0-2 \mathrm{~B})$, Calamintha clinopodium $(n=18+$ $0-1 \mathrm{~B})$ and Hemigraphis latebrosa $(n=12+0-2 \mathrm{~B})$ and Veronica anagallis-aquatica $(n=18+2 \mathrm{~B})$; varied chromosome counts: Calamintha clinopodium $(n=18)$, Hemigraphis latebrosa $(n=12)$, Justicia diffusa ( $n=16)$ and Lindenbergia indica $(n=25)$; euploid cytotypes: Lepidagathis hyalina $(n=30)$ and Veronica persica $(n=7)$. Two species, Veronica persica $(n=7,14)$ and Veronica anagallis-aquatica $(n=18+2 \mathrm{~B})$, have been counted for the first time in India. A comparison of morphological characters in the above listed interesting taxa has been made.
\end{abstract}

Key words Acanthaceae, B-Chromosomes, Varied chromosome numbers, Euploid, Lamiaceae, Scrophulariaceae.

Acanthaceae, Lamiaceae and Scrophulariaceae are important families of the Bicarpellatae series of subclass gamopetalae of dicot angiosperms. With its 2,500 species in 250 genera (Airyshaw 1973), Acanthaceae (or Acanthus family) is one of the larger families in the plant kingdom. Members of this family are chiefly distributed in the tropics and sub-tropics and show much variation in habit. Medicinally important plants, such as Adhatoda vasica, Asteracantha longifolia, Barleria cristata, grow throughout India. The Strobilathes alatus is grown as an ornamental plant.

Lamiaceae (the mint family) comprises over 240 genera and 6,500 species worldwide and its members produce a wide array of aromatic compounds (terpenoids), and they have been used for a number of medicinal purposes. Common wild species used for medicinal purposes are: Ajuga bracteosa, Anisomeles indica, Calamintha clinopodium, Leonurus cardiaca, Leucas cephalotes, Nepeta hindostana, Origanum vulgare and Prunella vulgaris; common as ornamentals are: Lamiun album and L. amplexicaule.

The Scrophulariaceae (or Figwort family) embraces 220 genera and around 3,000 species, comprising mostly of herbaceous plants distributed throughout the world. Scrophulariaceae is best known for its ornamental species e.g. Antirrhinum (snapdragon), Penstemon, Mimulus, Majus japonicas, Cymbalaria, and Digitalis (foxglove). Digitalis is also famous as the original source of digitalin and digitoxin, 2 drugs used in the treatment of heart problems. Lindenbergia indica and Verbascum thapsus are used for medicinal purposes.

Most of the chromosome studies on these families were carried out from South and Central India with scattered reports from North India. There are reports on chromosome numbers but no detailed cytogenetical investigations seem to have been carried out on these families from North India. The present attempt has been made in view of the economic importance of members of these families. The present paper deals with the detailed cytological analysis of 76 natural populations of

\footnotetext{
*Corresponding author, e-mail: santosh_gamo@rediffmail.com
} 
37 species of 3 families: Acanthaceae, Lamiaceae and Scrophulariaceae.

Materials and methods

For meiotic studies, usual acetocarmine smears of appropriate sized young flower buds were made after fixing them in Carnoy's fixative. Pollen fertility was estimated by mounting mature pollen grains in glycerol-acetocarmine. Materials for the present studies were collected from the Kangra district of Himachal Pradesh, covering altitude range between 490-3,300 m. Specific localities along with the altitude of various taxa are presented in Table 1. Voucher specimens are available in the Herbarium, Department of Botany, Punjabi University, Patiala (PUN).

\section{Results and discussion}

The haploid $(n)$ chromosome numbers in the investigated species along with specific locality, accession numbers (PUN) and previous chromosome reports are presented in the Table 1 . The families, genera and species are arranged alphabetically under their respective families. Only the interesting taxa are described in detail.

\section{Hemigraphis latebrosa (Roth) Nees}

It is a common herb mostly distributed between $500-1,600 \mathrm{~m}$ altitudes. Two accessions from Galua and Jarpali exhibited 12 bivalents. Additionally, in some cells 2 B-chromosomes were observed (Fig. 1). This varied chromosome count has been made for the first time on a worldwide basis, as the present report is not accordance with the previous reports of $n=7$ (Vasudevan 1976) and $n=14$ (Sareen and Sanjota 1976, Bir and Saggoo 1979). Earlier 3 species of the genus have been worked out which showed $n=7,14,15$ and 16 . The chromosome number presently found $(n=12)$ is new to the species as well as the genus.

The meiotic course in the Galua accession is abnormal due to the occurrence of laggards and bridges during anaphases/telophases, with high pollen fertility (96\%). On the other hand, the accession from Jarpali has no meiotic abnormality and has cent per cent pollen fertility. Morphologically, the Jarpali population shows robust habit in terms of plant height, leaf size and petiole length.

\section{Justicia diffusa Willd.}

Meiotic studies revealed 16 bivalents at metaphase-I (Fig. 2). This chromosome number has been worked out for the first time on a worldwide basis, as the previous reports are of $n=9$ from India (Bir and Sidhu 1980, Vasudevan 1976, Valsala and Mathew 1982) and from outside India (Khatoon and Ali 1993). The common gametic chromosome numbers known in the genus are $n=9$, 11,13 and 14 . The chromosome number presently found $(n=16)$ is new to the species as well as the genus.

Meiosis in both accessions is normal with high pollen fertility.

Lepidagathis hyalina Nees

This is common in Sal forests between $400-1500 \mathrm{~m}$. The present studies showed the presence of $n=30$ at metaphase-I (Fig. 3). This is the first record of the hexaploid cytotype on a worldwide basis, as the previous record for the species is of $n=10$ (Bir and Saggoo 1981).

Ajuga bracteosa Wall.

The species is common in dry, sandy places and on rocks between altitudes of 500-800 $\mathrm{m}$. The present investigations have been made on 3 accessions of the species which represents 3 morpho- 
Table 1. Information on taxa, voucher data, accession number, chromosome number and previous chromosome reports of presently investigated species of the Bicarpellatae series.

\begin{tabular}{|c|c|c|c|c|c|}
\hline \multirow{2}{*}{ Name of taxa } & \multirow{2}{*}{$\begin{array}{c}\text { Voucher data } \\
\text { (Locality with altitude) }\end{array}$} & \multirow{2}{*}{$\begin{array}{c}\text { Accession } \\
\text { number } \\
\text { (PUN) }\end{array}$} & \multirow{2}{*}{$\begin{array}{c}\text { Meiotic } \\
\text { chromosome } \\
\text { number }(n)\end{array}$} & \multicolumn{2}{|c|}{$\begin{array}{l}\text { Previous chromosome } \\
\text { reports }(2 n)\end{array}$} \\
\hline & & & & India & World \\
\hline \multicolumn{6}{|l|}{ FAMILY: ACANTHACEAE } \\
\hline \multirow[t]{4}{*}{ Adhatoda vasica Nees } & Bankhandi, $557 \mathrm{~m}$ & 53050 & 17 & 34 & 56 \\
\hline & Shahpur, $780 \mathrm{~m}$ & 53051 & 17 & & \\
\hline & Trilokpur, $615 \mathrm{~m}$ & 53052 & 17 & & \\
\hline & Jarpali, $501 \mathrm{~m}$ & 53053 & 17 & & \\
\hline Asteracantha longifolia Nees & Shahpur, $780 \mathrm{~m}$ & 53034 & 16 & 32 & \\
\hline Barleria cristata Linn. & Shahpur, $780 \mathrm{~m}$ & 53211 & 19 & $34,36,38,40$ & 40 \\
\hline \multirow[t]{3}{*}{ Dicliptera bupleroides Nees } & Banuri, $1300 \mathrm{~m}$ & 53212 & 13 & 26,52 & \\
\hline & Nagrota Surian, $530 \mathrm{~m}$ & 53213 & 13 & & \\
\hline & Shahpur, $780 \mathrm{~m}$ & 53214 & 13 & & \\
\hline $\begin{array}{l}\text { Eranthemum nervosum (Vahl) } \\
\text { R.Br. ex. Roem. \& Schult. }\end{array}$ & Jarpali, $501 \mathrm{~m}$ & 53042 & 11 & 42,44 & \\
\hline \multirow{2}{*}{$\begin{array}{l}\text { *Hemigraphis latebrosa (Roth) } \\
\text { Nees }\end{array}$} & Galua, 595 m & 53049 & 12 & 14,28 & \\
\hline & Jarpali, $501 \mathrm{~m}$ & 53074 & $12+0-2 \mathrm{~B}$ & & \\
\hline \multirow[t]{2}{*}{ *Justicia diffusa Willd. } & Dharamkot, $2200 \mathrm{~m}$ & 53046 & 16 & 18 & \\
\hline & Shahpur, $780 \mathrm{~m}$ & 53047 & 16 & & \\
\hline \multirow[t]{3}{*}{ Lepidagathis cuspidata Nees } & Mecleodganj, $1780 \mathrm{~m}$ & 53039 & 11 & 22 & \\
\hline & Shahpur, $780 \mathrm{~m}$ & 53040 & 11 & & \\
\hline & Salli, $1500 \mathrm{~m}$ & 53041 & 11 & & \\
\hline \multirow[t]{3}{*}{ *Lepidagathis hyalina Nees } & Galua, $595 \mathrm{~m}$ & 53043 & 30 & 20 & \\
\hline & $32 \mathrm{Meel}, 620 \mathrm{~m}$ & 53044 & 30 & & \\
\hline & Dehra Gopipur, 490 m & 53045 & 30 & & \\
\hline Peristrophe bicalyculata Retz. & Nagrota Surian, $530 \mathrm{~m}$ & 53048 & 15 & 20,30 & 30 \\
\hline \multirow[t]{4}{*}{ Strobilanthes alatus Nees } & Mecleodganj, $1780 \mathrm{~m}$ & 53035 & 16 & 32 & \\
\hline & Dharamkot, $2200 \mathrm{~m}$ & 53036 & 16 & & \\
\hline & Multhan, $2000 \mathrm{~m}$ & 53037 & 16 & & \\
\hline & Swar, $2500 \mathrm{~m}$ & 53038 & 16 & & \\
\hline \multicolumn{6}{|l|}{ FAMILY: LAMIACEAE } \\
\hline \multirow[t]{3}{*}{ *Ajuga bracteosa Wall. } & Dehra Gopipur, $490 \mathrm{~m}$ & 53014 & 32 & 32,64 & 32 \\
\hline & Masroor, $617 \mathrm{~m}$ & 53015 & 32 & & \\
\hline & Nagrota Surian, $530 \mathrm{~m}$ & 53016 & $32+0-2 B$ & & \\
\hline $\begin{array}{l}\text { Ajuga macrosperma Wall. ex } \\
\text { Benth. }\end{array}$ & Masroor, $617 \mathrm{~m}$ & 53011 & 16 & 32 & 16 \\
\hline \multirow[t]{2}{*}{ Ajuga parviflora Benth. } & Palampur, $1219 \mathrm{~m}$ & 53012 & 16 & & \\
\hline & Bir, $1300 \mathrm{~m}$ & 53013 & 16 & & \\
\hline \multirow{3}{*}{$\begin{array}{l}\text { Anisomeles indica (Linn.) O. } \\
\text { Kuntze }\end{array}$} & Shahpur, $780 \mathrm{~m}$ & 52988 & 17 & $32,32+0-2 \mathrm{~B}$ & \\
\hline & Dehra Gopipur, $490 \mathrm{~m}$ & 52989 & 17 & & \\
\hline & Nagrota Surian, $530 \mathrm{~m}$ & 52990 & 17 & & \\
\hline \multirow[t]{3}{*}{ *Calamintha clinopodium Benth. } & Bir, $1300 \mathrm{~m}$ & 53017 & $18+0-1 \mathrm{~B}$ & 20,34 & 20 \\
\hline & Palampur, $1219 \mathrm{~m}$ & 53018 & 18 & 20 & \\
\hline & Multhan, 2000 m & 53019 & 18 & & \\
\hline Lamium amplexicaule Linn. & Nagrota Surian, $530 \mathrm{~m}$ & 53000 & 9 & 18 & 18 \\
\hline Leonurus cardiaca Linn. & Lohardi, $2200 \mathrm{~m}$ & 53038 & 9 & 18 & 18 \\
\hline
\end{tabular}


Table 1. (Continued)

\begin{tabular}{|c|c|c|c|c|c|}
\hline \multirow[t]{2}{*}{ Name of taxa } & \multirow{2}{*}{$\begin{array}{c}\text { Voucher data } \\
\text { (Locality with altitude) }\end{array}$} & \multirow{2}{*}{$\begin{array}{l}\text { Accession } \\
\text { number } \\
\text { (PUN) }\end{array}$} & \multirow{2}{*}{$\begin{array}{c}\text { Meiotic } \\
\text { chromosome } \\
\text { number }(n)\end{array}$} & \multicolumn{2}{|c|}{$\begin{array}{l}\text { Previous chromosome } \\
\text { reports }(2 n)\end{array}$} \\
\hline & & & & India & World \\
\hline Leucas cephalotes (Roth) Spreng. & Nagrota Surian, $530 \mathrm{~m}$ & 53020 & 11 & $18,22,28$ & \\
\hline \multirow[t]{2}{*}{ Leucas lanata Benth. } & Banuri, $1300 \mathrm{~m}$ & 52998 & 14 & 28 & \\
\hline & Shahpur, $780 \mathrm{~m}$ & 52999 & 14 & & \\
\hline \multirow{2}{*}{$\begin{array}{l}\text { Micromeria biflora (Buch.-Ham.) } \\
\text { Benth. }\end{array}$} & Banuri, $1300 \mathrm{~m}$ & 53027 & 15 & 30 & 30 \\
\hline & Nagrota Surian, $530 \mathrm{~m}$ & 53028 & 15 & & \\
\hline \multirow[t]{3}{*}{ Nepeta hindostana (Roth) Haines } & Tiara, $810 \mathrm{~m}$ & 53001 & 18 & 18,36 & \\
\hline & Sakri-Bilaspur, $527 \mathrm{~m}$ & 53003 & 18 & & \\
\hline & Dyot, $2037 \mathrm{~m}$ & 53004 & 18 & & \\
\hline Nepeta leucophylla Benth. & Multhan, $2000 \mathrm{~m}$ & 53361 & 18 & 36 & \\
\hline Plectranthus rugosus (Wall.) & Salli, $1500 \mathrm{~m}$ & 53022 & 12 & 24 & \\
\hline Plectranthus striatus Benth. & Salli, $1500 \mathrm{~m}$ & 53021 & 12 & 24 & \\
\hline $\begin{array}{l}\text { Pogostemon benghalensis (Bum. f.) } \\
\quad \text { O. Kuntze }\end{array}$ & Bankhandi, $557 \mathrm{~m}$ & 53030 & 32 & 42,64 & \\
\hline Prunella vulgaris Linn. & Multhan, $2000 \mathrm{~m}$ & 53023 & 14 & 28 & 28,32 \\
\hline \multirow[t]{2}{*}{ Salvia coccinia Jull. ex Murr. } & Gaggal, $770 \mathrm{~m}$ & 21827 & 11 & 22 & 20,22 \\
\hline & Masroor, $617 \mathrm{~m}$ & 21828 & 11 & & \\
\hline \multirow[t]{3}{*}{ Salvia plebeia $\mathrm{R} . \mathrm{Br}$. } & Dehra Gopipur, $490 \mathrm{~m}$ & 52994 & 8 & 16,32 & 16 \\
\hline & Nagrota Surian, $527 \mathrm{~m}$ & 52995 & 8 & & \\
\hline & Jarpali, $501 \mathrm{~m}$ & 52996 & 8 & & \\
\hline $\begin{array}{l}\text { Scutellaria repens Buch.-Ham. ex } \\
\text { D. Don }\end{array}$ & Tiara, $810 \mathrm{~m}$ & 53072 & 10 & $20,20+1 B$ & \\
\hline \multirow[t]{2}{*}{ Stachys sericea Wall. } & Lohardi, $2200 \mathrm{~m}$ & 53007 & 15 & 30 & \\
\hline & Badagaon, $3300 \mathrm{~m}$ & 53009 & 15 & & \\
\hline \multicolumn{6}{|l|}{ FAMILY: SCROPHULARIACEAE } \\
\hline \multirow[t]{4}{*}{ *Lindenbergia indica (Linn.) Vatke } & Tiara, $810 \mathrm{~m}$ & 53067 & 25 & 30 & 30 \\
\hline & Dharamshala, $1500 \mathrm{~m}$ & 53068 & 25 & & \\
\hline & Dyot, $2037 \mathrm{~m}$ & 53070 & 25 & & \\
\hline & Nagrota Surian, $530 \mathrm{~m}$ & 53071 & 25 & & \\
\hline \multirow{3}{*}{$\begin{array}{l}\text { Mazus japonicus (Thumb.) O. } \\
\text { Kuntze }\end{array}$} & Nagrota Surian, $530 \mathrm{~m}$ & 53056 & 20 & 40,52 & 38,40 \\
\hline & Bassa, $490 \mathrm{~m}$ & 53057 & 20 & & \\
\hline & Galua, $595 \mathrm{~m}$ & 53058 & 20 & & \\
\hline $\begin{array}{l}\text { Scrophularia himalensis Royle ex } \\
\text { Benth. }\end{array}$ & Lohardi, $2200 \mathrm{~m}$ & 53060 & 24 & $48+2-4 B$ & \\
\hline \multirow[t]{5}{*}{ Verbascum thapsus Linn. } & Harchhakian, $600 \mathrm{~m}$ & 53061 & 18 & 34,36 & 34,36 \\
\hline & Bir, $1300 \mathrm{~m}$ & 53062 & 18 & & \\
\hline & Palampur, $1219 \mathrm{~m}$ & 53064 & 18 & & \\
\hline & Dyot, $2037 \mathrm{~m}$ & 53065 & 18 & & \\
\hline & Badagaon, $3300 \mathrm{~m}$ & 53066 & 18 & & \\
\hline *Veronica anagallis-aquatica Linn. & Nagrota Surian, $530 \mathrm{~m}$ & 53059 & $18+0-2 \mathrm{~B}$ & & 18,36 \\
\hline \multirow[t]{2}{*}{ *Veronica persica Poir } & Nagrota Surian, $530 \mathrm{~m}$ & 53054 & 7 & & 28 \\
\hline & Palampur, $1219 \mathrm{~m}$ & 53055 & 14 & & \\
\hline
\end{tabular}

* New records 

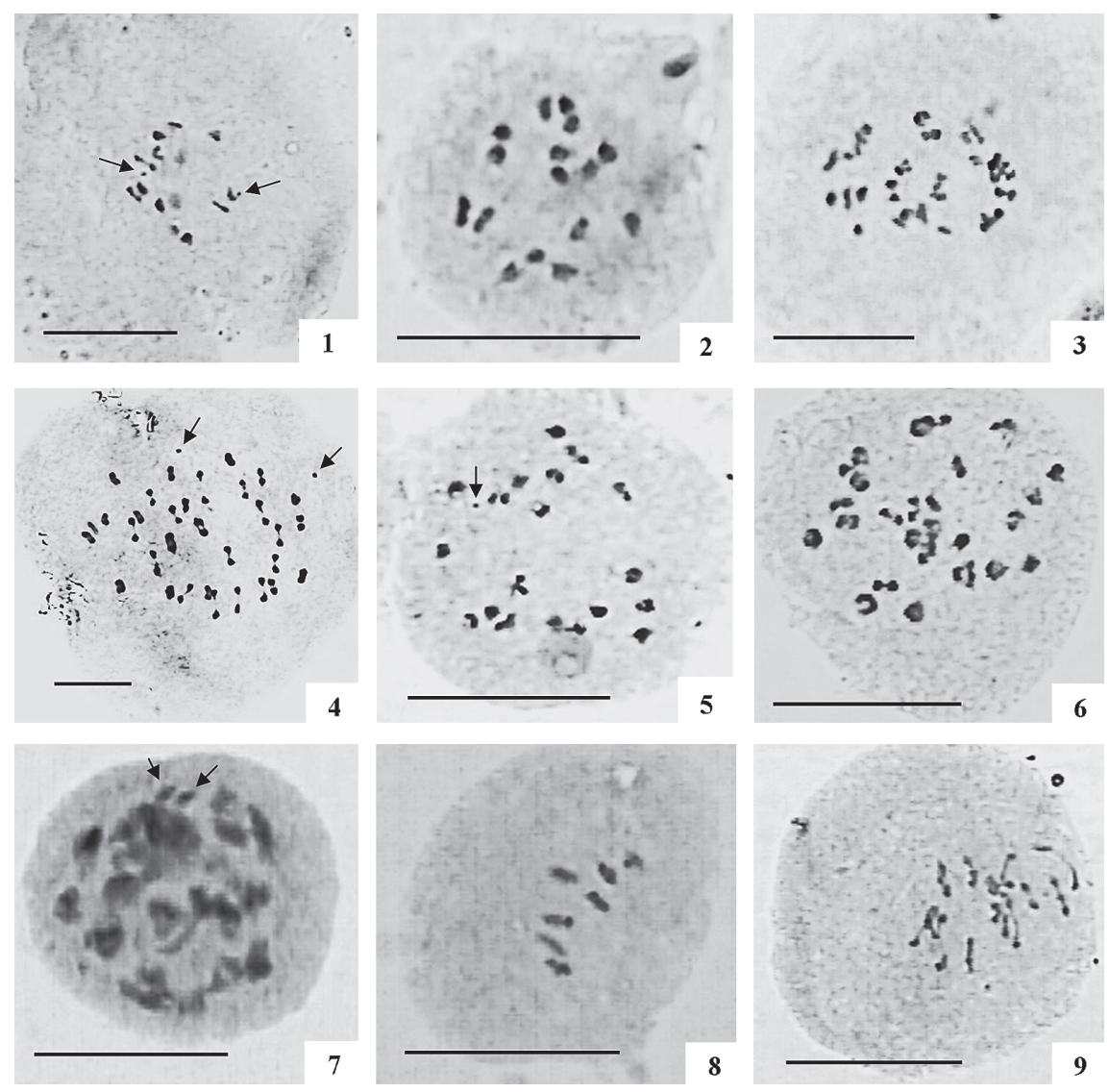

Figs. 1-9. Meiotic analysis. (Scale bar=10 $\mu \mathrm{m}$ ). 1. Hemigraphis latebrosa. PMC at Metaphase-I with $n=12+0-2 \mathrm{~B}$ (arrows). 2. Justicia diffusa. PMC at Metaphase-I with 16 bivalents. 3. Lepidagathis hyalina. PMC at Metaphase-I with 30 bivalents. 4. Ajuga bracteosa. PMC at Metaphase-I with $n=32+0-2 \mathrm{~B}$ (arrows). 5. Calamintha clinopodium. PMC at diakinesis with $n=18+0-1 \mathrm{~B}$ (arrow). 6. Lindenbergia indica. PMC at Metaphase-I with 25 bivalents. 7. Veronica anagallis-aquatica. PMC at diakinesis with $n=18+0-2 \mathrm{~B}$ (arrows). 8, 9. Veronica persica 8. PMC at Metaphase-I with 7 bivalents. 9. PMC at Metaphase-I with 14 bivalents.

types on flower color basis (white blue, pure white and white purple).

All the accessions are tetraploid with $n=32$. The Nagrota Surian population shows up to 2 B chromosomes in some cells (Fig. 4). The present report of $n=32$ is in accordance with previous records (Bir and Saggoo 1981, Chuang et al. 1963, Gill 1984), but the B-chromosomes are reported for the first time. Already the B-chromosomes are known in A. parviflora $(2 n=32+0-2 \mathrm{~B})$ by Bir and Sagoo (1982).

Meiosis in all the accessions is abnormal with the presence of univalents, unoriented bivalents, secondary chromosomal associations and cytomixis in the Nagrota Surian accession, and only a few laggards in the Masroor and Dehra Gopipur accessions.

Calamintha clinopodium Benth.

The present study on the accessions of Bir and Palampur revealed 18 bivalents. In addition to 18 bivalents, 1B-chromosome is also reported (Fig. 5). This chromosome number has been worked out for the first time on a worldwide basis, as the present report is not accordance with the previous reports of $n=10$ from India (Gill 1984, Saggoo 1983) and from outside India (Löve 1954, Majovsky 
et al. 1970, Reese 1953, Scheerer 1939). The various chromosome numbers already known in the genus Calamintha are: $n=5,9,10,11,12,18,19,21,23$ and 24 . Thus, the chromosome number $n=18$ is already known in the genus but is newly reported for the present species. Meiosis in both accessions is normal with high pollen fertility.

Lindenbergia indica (Linn.) Vatke

It is commonly distributed in open slopes between altitudes of 500-2010 m. All 4 accessions from various localities of the Kangra District showed $n=25$ (Fig. 6). The previous reports are of $n=15$ from India (Thakur 1978, Trivedi and Trivedi 1992) and from outside India (Khatoon and Ali 1993).

Tiara and Dyot accessions show normal meiosis with a high percentage of pollen fertility (96-98\%). However, the Dharamshala and Nagrota Surian accessions are abnormal with the presence of laggards; monads, dyads, triads and tetrads with or without micronuclei. In these, the pollen fertility is slightly low (86-89\%).

Veronica anagallis-aquatica Linn.

It is a cosmopolitan species, very commonly found on marshy grounds and along banks of streams. The indian population of the species has been worked out for the first time with $n=18$. In addition this 2 B-chromosomes were also observed (Fig. 7) and the present record is in conformity with previous chromosome reports (Bjorkqvist et al. 1969, Ozturk and Fischer 1982, Dalgaard 1985). Presence of B-chromosomes is reported for the first time. Meiotic course is mostly normal except for the presence of some laggards and with high pollen fertility (98\%).

\section{Veronica persica Poir}

It is a common species, distributed on moist and shady places between 500-2000 m. Here, the Indian population of the species has been worked out for the first time. Two cytotypes have been observed, diploid ( $n=7$, Fig. 8) from Nagrota Surian and tetraploid ( $n=14$, Fig. 9) from Palampur.

The present chromosome count of $n=7$ in the species is the first ever record of diploid cytotype on a worldwide basis. The chromosome count of $n=14$ for the species has been counted for the first time in India and is in conformity with the previous records from outside India (Hill 1989, Chuang and Heckard 1992, Mulligan 1959, Yamashita 1937). Meiosis in both accessions is normal. The pollen fertility is cent per cent in diploid and low (84\%) in the tetraploid cytotype.

Morphologically, the tetraploid cytotype shows taller plants with fewer branches per plant and dark green colored leaves as compared to the diploid cytotype.

\section{Conclusion}

New chromosome data for these North Indian species showed B-chromosomes, varied chromosome counts, euploid cytotypes and 2 species counted for the first time from India. A total of 11 species of Acanthaceae family, presently investigated from the study area, show 7 diploids and 4 polyploids. Previous chromosome data reveals that the family is polybasic $(x=7,9,10,11,13$, 15,16 and 17). The present study adds up 1 euploid cytotype $(2 n=6 x=60)$ for Lepidagathis hyalina and 2 varied chromosome numbers i.e. $2 n=24,24+0-2 \mathrm{~B}$ for Hemigraphis latebrosa and $2 n=32$ for Justicia diffusa. This is the first time that $n=12$ has been reported in the H. latebrosa and $n=16$ in J. diffusa.

In the family Lamiaceae, a total of 20 species are presently investigated, out of which 16 are diploids and 4 polyploids. Like Acanthaceae, Lamiaceae is also polybasic $(x=8,9,10,11,12$, $14,15,16$ and 17). The present study adds up 1 new chromosome number: $2 n=36 ; 36+0-1 \mathrm{~B}$ for Calamintha clinopodium and B-chromosomes $(2 n=64+0-2 \mathrm{~B})$ for Ajuga bracteosa. 
In the Scrophulariaceae family, a total of 6 species are presently investigated, out of which 3 are diploids, 2 polyploids and 1 species with diploid as well as polyploid cytotypes. A new chromosome number $(2 n=50)$ for Lindenbergia indica; a new cytotype $(2 n=2 x=14)$ for Veronica persica; and B-chromosomes $(2 n=36+2 \mathrm{~B})$ for Veronica anagallis-aquatica have been recorded.

\section{Acknowledgements}

The authors are thankful to DRS SAP-II, ASIST Programme and Rajiv Gandhi National Fellowship Scheme under UGC, New Delhi for financial assistance.

\section{References}

Airyshaw, H. K. 1973. A dictionary of flowering plants and ferns. Willis, J. C. (ed.). Cambridge University Press, Cambridge. pp. ixxii, 1-1245.

Bjorkqvist, I. R., Bothmer, V., Nilson, O. and Nordenstam, B. 1969. Chromosome numbers in Iberian Angiosperms. Nord. J. Bot. 122: 271-283.

Bir, S. S. and Saggoo, M. I. S. 1979. In IOPB chromosome number reports LXV. Taxon 28: 630-631.

— and - 1981. Cytopalynology of certain Acanthaceae and Labiatae. Journal of Palynology 17: 93-102.

— and - 1982. In: IOPB chromosome number reports LXXVII. Taxon 31: 775.

— and Sidhu, M. 1980. Cyto-palynological studies on weed flora of cultivable lands of Patiala district (Punjab). Journal of Palynology 16: 85-105.

Chuang, T. I. and Heckard, L. R. 1992. Chromosome numbers of some North American Scrophulariaceae, mostly Californian. Madroño 39(2): 137-149.

-, Chao, C.Y., Hu, W. W. L. and Kwan, S. C. 1963. Chromosome numbers of vascular plants of Taiwan. I.-Taiwania 1: 51-66.

Dalgaard, V. 1985. Chromosome studies in flowering plants from Madeira. Willdenowia 15: 137-156.

Gill, L. S. 1984. The incidence of polyploidy in the West-Himalayan Labiatae. Revue de Cytologie et de Biologie Végétales, le Botaniste 7: 5-16.

Hill, L. M. 1989. IOPB chromosome data 1. International Organization of Plant Biosystematists Newsletter 13: 17-19.

Khatoon, S. and Ali, S. I. 1993. Chromosome Atlas of the Angiosperms of Pakistan. Department of Botany, University of Karachi, Karachi.

Löve, A. 1954. Cytotaxonomical evaluation of corresponding taxa. Vegetatio 5-6: 212-224.

Majovsky, J. et al. 1970. Index of chromosome numbers of Slovakian flora (Part I). Acta Fac. Rerum Nat. Univ. Comenianae Bot. 16: 1-26.

Mulligan, G. A. 1959. Chromosome numbers of Canadian weeds. II. Can. J. Bot. 37(1): 81-92.

Ozturk, A. and Fischer, M. A. 1982. Karyosystematics of Veronica sect. Beccabunga (Scrophulariaceae) with special reference to the taxa in Turkey. Plant Syst. Evol. 140: 307-319.

Reese, G., 1953. Erganzende Mitteilungen uber die Chromosomenzahlen mitteleuropaischer Gefasspflanzen. II. Bot. Acta 66(1): 66-74.

Sareen, T. S. and Sanjota, K. 1976. Chromosome numbers in some species of Acanthaceae. Cytologia 41: $283-290$.

Saggoo, M. I. 1983. Cytomorphological studies on plants of economic importance of Bicarpellatae from India. 259 pp.

Scheerer, H. 1939. Chromosomenzahlen aus der Schleswig-holsteinischen Flora. I. Planta 29(4): 636-642.

Thakur, V. 1978. Chromosomal and nuclear transmigration during microsporogenesis in natural populations of some plant species. In: Dyansagar, V.R., et al. (eds.), Recent Trends and Contacts between Cytogenetics, Embryology and Morphology. Today and Tomorrow, New Delhi. pp. 123-130.

Trivedi, M. P. and Trivedi, R. N. 1992. Chromosomal behaviour in weeds. Glimpses of Cytogenetics in India 3: $188-198$.

Valsala Deri, G. and Mathew, P. M. 1982. In IOPB chromosome number reports LXXVII. Taxon 31: 773.

Vasudevan, K. N. 1976. Contribution to the cytotaxonomy and cytogeography of the flora of the western Himalayas (with an attempt to compare it with the flora of the Alps). Part III. Bot. Acta 86: 152-203.

Yamashita, K., 1937. Chromosomenzahlen einiger Veronica-Arten. Agric. Hort. (Tokyo) 12(6): 1219-1220. 